Fakultet za medije i komunikacije

Beograd, Srbija

danica.igrutinovic@fmk.edu.rs

DOI: $10.18485 /$ rit.2022.20.37.7

Originalni naučni rad

Datum prijema: 24.08.2021.

\title{
SLOBODA VEROISPOVESTI I/ILI SLOBODA GOVORA U POSTSEKULARNOJ EVROPI
}

\begin{abstract}
Rezime
Ovaj rad bavi se slobodom veroispovesti i slobodom govora u domenu kritike veroispovesti u državama članicama EU kroz tri osnovna modela (francuski, nemački i engleski) koje one imaju pri uređenju svojih odnosa sa religijskim zajednicama svojih građana. Osvrće se na potencijalne probleme ovih modela sekularnosti u oblasti prava na slobodu veroispovesti i slobodu govora, navodeći za svaki model bar po jedan primer šire poznatih kontroverzi iz XX i XXI veka.U zaključku se, nakon uočavanja opštih tendencija prisutnih u svakom od modela, postavlja nekoliko kratkih teorijskih pitanja vezanih za sekularnost države i društva - sa posebnim osvrtom na sekularnost javnog i medijskog prostora-u postsekularnom svetu.
\end{abstract}

Ključne reči: sloboda veroispovesti, sloboda govora, EU, modeli sekularnosti, postsekularno.

\section{Uvod}

U državama Evrope, posle prosvetiteljstva uglavnom je došlo do manjeg ili većeg distanciranja države od crkve. Jedna od bitnijih tekovina ove sekularizacije jeste po Libeu odvajanje veroispovedanja od građanskih prava, što ne mora da znači odvajanje crkve od države, ali mora da znači ustavno garantovanje slobode religije. Disidenti, apostate i ateisti imaju zakonom zagarantovana prava, a od države se zahteva da garantuje nezavisnost ljudskih prava od religije. Religijske institucije umnogome prestaju da budu sredstvo društvene kontrole (Lübbe 1986: 13).

Društveni teoretičari su dugo pretpostavljali da će se ovaj proces sekularizacije društva nezaustavljivo širiti i produbljivati do trenutka kad religioznost potpuno nestane sa lica zemlje. Marks je bio optimista - religija kao opijum za narod koji je bio nužan zbog teškog položaja u kome se nalaze potlačeni po njemu će prosto nestati kad za njim prestane potreba; 
doduše, ne bi se moglo ni reći da je potreba nestala jer više nema potlačenih koji su u teškom položaju. Frojd je verovao da će neizbežni proces ljudskog rasta iskoreniti religioznost, a Dirkem je je izneo poetski stav da „bogovi stare ili umiru“. Međutim, u većini država proces sekularizacije se u poslednjim decenijama obrnuo, te posve nereligiozni građani uglavnom predstavljaju gotovo zanemarljivu manjinu (Berlinerblau 2005: 1-2).

Nakon doba sekularizacije, počelo se govoriti o postsekularnom dobu, koje bi najšire govoreći moglo da okarakteriše shvatanje da teorija sekularizacije nije održiva, te da religija nastavlja da igra ulogu u društvu, politici i javnom životu. Ta uloga ne može biti ista kao pre sekularizacije država i društava, pa je u toku proces iznalaženja novih modela, i pitanje njihovog konačnog oblika ostaje još uvek otvoreno. Povratak religioznosti izazvao je različite reakcije u Evropi, od kojih Zuka izdvaja tri osnovna smera. Neki su otišli u tvrdi sekularizam, zahtevajući oštru podelu na javne i privatne domene, pri čemu religioznost spada u potonji. Drugi su poželeli da utvrde identitetske korene evropejstva u hrišćanskoj tradiciji kao neprikosnovene - zaboravljajući međuhrišćanske konflikte koji su obeležili dobar deo istorije Evrope i zbog kojih su, između ostalog, sekularnost i privatnost religije i uvedeni i često bivali korisni. Postoji i kvazireligijska tendencija ka apoteozi pravne države, demokratije i ljudskih prava, koji se kao panacea za sve probleme navode $\mathrm{u}$ formi verskih doktrina umesto da se njihove prednosti brane argumentima (Zucca 2012: XVII).

Mi ćemo se ovde najviše baviti idejom sekularnosti države i društva jer je ona u dobroj meri u teoriji i praksi prisutna u većini Evrope. Za početak, dobro je dekonstruisati koncept sekularnosti kao vrednosno i kulturno neutralnog koncepta. Talal Asad primećuje da je sekularnost itekako vrednosno obojena ideja te da izaziva asocijacije ne samo na nereligioznost, već na toleranciju, humanističku orijentaciju, savremenost, progresivnost, hrišćansko kulturno poreklo, ili prosto - zapad. Zamišljeni i suprotstavljeni Drugi ove sekularnosti u Evropi koji joj i daje dobar deo značenja po Asadu je umnogome islam i time se može sakriti kulturno hrišćanski sadržaj zapadnog javnog života; s druge strane, hrišćanska desnica često napada „sekularni humanizam“ zbog uništenja porodičnih vrednosti i patriotizma (Asad et al. 2009: 10). Moglo bi se reći da je sekularnost vrednost hrišćanskog zapada koji ne priznaje i ne primećuje da je hrišćanski, već sebe smatra kulturno neutralnim, objektivnim, racionalnim, i nadasve superiornim. 


\section{Sloboda veroispovesti i/ili sloboda govora}

Moglo bi se reći da sloboda veroispovesti i sloboda govora pripadaju istoj opštoj slobodi samoizražavanja. Lerner podseća da je pravo na slobodu veroispovesti istorijski nastalo pre drugih ljudskih prava, u bilateralnim mirovnim sporazumima u kojima se prilagođavalo tradicionalno pravilo cuius regio eius religio da pokrije recipročnu zaštitu verskih manjina na određenoj teritoriji (Lerner 2006: 3). Po članu 6(2) Evropskog „ustava“, sloboda veroispovesti podrazumevana je među osnovnim pravima zagarantovanim od strane Evropskog suda za ljudska prava. Član 9 evropske konvencije za zaštitu ljudskih prava i osnovnih sloboda štiti versku slobodu kao pravo pojedinca i zajednica (Robbers 2005: 13). Sloboda veroispovesti se daje uz određena neophodna ograničenja koja su „u skladu sa zakonima država članica“ $i$,neophodna u demokratskom društvu“ $u$ interesu bezbednosti, zaštite javnog reda, zdravlja ili morala, ili radi zaštite prava i sloboda drugih. Trenutno aktuelna pandemija je jasno pokazala da se ova ograničenja brzo i lako mogu primeniti u svim državama sveta.

Član 10 pak garantuje slobodu govora - takođe uz određena neophodna ograničenja koja su „u skladu sa zakonima država članica“ i „neophodna u demokratskom društvu“. Opet, u situaciji pandemije i vanrednog stanja, očito je moguće više ograničiti ovu slobodu nego obično, pod izgovorom sprečavanja ,širenja panike“ ili tome slično. Sloboda govora se u Evropi razvijala prvo nasuprot verskim, a zatim i svetovnim autoritetima, koji su težili da potisnu širenje 'opasnih' ideja, posebno nakon izuma štamparske mašine. Francuska je, recimo, mučila pa na lomači spalila štampara Etjena Dolea, a u Bastilji se u trenutku njenog pada nalazilo oko osam stotina autora i štampara (Pool 1983: 15).

Kako balansiranje ove dve slobode funckcioniše u EU i ima li to veze sa modelom sekularnosti država članica?

Nacrt Evropskog „ustava“ ima preambulu o verskom nasleđu nepovezanu sa pitanjem odnosa države i crkve. Član I-52 tiče se statusa crkava i verskih zajednica: 1.) Unija poštuje i ne prejudicira položaj crkava i verskih udruženja i zajednica po nacionalnom pravu država članica. 2.) Unija jednako poštuje status filozofskih i nekonfesionalnih organizacija. 3.) Priznajući njihov identitet i njihov poseban doprinos, Unija će održavati otvoren, transparentan i redovan dijalog sa ovim crkvama i organizacijama (Robbers 2005: 14-15). 
Države članice imaju dosta slobode pri uređenju sopstvenih odnosa sa verskim zajednicama, a zaštita kulturnog nasleđa je svakako neprikosnovena.

Da bismo pokušali da shvatimo kako ovo u teoriji i praksi može da funkcioniše, pogledaćemo zakone i njihove praktične primene kroz tri osnovna tipa sistema uređenja odnosa između države i verskih organizacija u EU: 1.) Postojanje državne crkve ili dominantne religije - Engleska, Danska, Malta, Grčka, Finska. 2.) Ideja stroge razdvojenosti najčeše nazivan laïcité - Francuska, Holandija, Irska. 3.) Osnovna razdvojenost uz zajedničke zadatke - Nemačka, Poljska, Belgija, Mađarska, Austrija, Portugal, baltičke države, Italija, Španija (Robbers 2005: 10; v. Sima Avramović u Bigović 2003: 49).

Navešćemo neke od zakona vezanih za slobodu govora i slobodu veroispovesti koji postoje u državama predstavnicama ovih modela, kao i bar po jedan primer slučaja vezanog za pravo na slobodu govora i/ili veroispovesti koji je privukao međunarodnu pažnju. Na kraju ćemo da pokušamo da izvedemo neke opšte zaključke vezane za svaki model, ukoliko je takvo što iole moguće.

Liminalna mesta na kojima se dodiruju i sukobljavaju javno i privatno, javni zakon i religijska praksa, biće posebno zanimljivi. U kom trenut$\mathrm{ku}$ javno iskazivanje religijske pripadnosti postaje problem onima koji je ne dele: svetosavska priredba ili hidžab u školama? U kom trenutku javno iskazivanje kritike ili podsmeha doktrinama ili simbolima jedne religije postaje problem onima koji je ispovedaju: karikature Muhameda ili ikona Bogorodice sa oreolom u duginim bojama na Paradi ponosa? Kako različiti modeli sekularnosti nalaze put između Skile i Haribde ovih različitih načina korišćenja iste slobode samoizražavanja?

\section{Engleski model: državna crkva}

Kao države koje pripadaju 'engleskom' modelu državne ili zakonski povlašćene crkve pominju se Engleska, Danska, Malta, Grčka i Finska. Švedska takođe de facto pripada ovoj skupini jer i pored zvaničnog ukidanja državne veroispovesti 2000. godine još uvek ima Zakon o Švedskoj crkvi kao za državu bitnoj instituciji.

U Grčkoj od sticanja nezavisnosti zvanično postoji državna Grčka Pravoslavna Crkva. Godine 2000. Vlada je posle dugih najava i debata izbacila podatak o veroispovesti iz ličnih karata da bi sprečila diskriminaci- 
ju po verskoj osnovi, što je izazvalo burne reakcije među sveštenstvom i građanima i pokazalo da je odnos ipak potencijalno problematičan. Crkva je u debati insistirala na pravoslavlju kao ključnoj odrednici grčkog identiteta i time elementu državnosti koji nikako ne može biti u privatnoj sferi (Jablanov Maksimović 2009: 331-2; 334). Zbog izuzetno tvrdog stava koji zvanična Grčka, bar u odnosu na većinu ostalih država članica EU, ima $\mathrm{u}$ isticanju statusa zvanične državne veroispovesti, poslednjih nekoliko decenija dosledno je gubila tužbe za diskriminaciju nad svojim nepravoslavnim građanima pred Evropskom komisijom za ljudska prava i Evropskim sudom za ljudska prava (Jablanov Maksimović 2009: 347). Činjenica da je prozelitizam krivično delo dovela je do međunarodno poznatog slučaja Kokinakis v. Grčka, što je prvi slučaj u kome se Evropski sud za ljudska prava bavio slobodom veroispovesti. Kokinakis, Jehovin svedok koji je više puta kažnjavan zatvorskom kaznom zbog prozelitizma, jednom kada je sveštenik na čija vrata je pokucao pozvao policiju koja ga je odmah uhapsila, tvrdio je da je takav njegov tretman kršenje prava na slobodu veroispovesti. Grčki sudovi su smatrali da je zakon o prozelitizmu u skladu sa Ustavom Grčke, po kome je Grčka Pravoslavna Crkva državna veroispovest, a sve ostale religije imaju jednaku zabranu da šire svoje ideje, ne samo Jehovini svedoci, kao i da je ova zabrana u skladu sa slobodom veroispovesti. Ovo potonje je osporeno pred Evropskim sudom za ljudska prava, koji je doneo odluku da je u ovom slučaju država prekomerno ograničila slobodu veroispovesti (Zucca 2012: 51).

U Ujedinjenom Kraljevstvu zvanična crkva je Anglikanska, čiji je vrhovni poglavar uvek monarh koji je trenutno na tronu. Zakoni o blasfemiji koji su donedavno postojali u Ujedinjenom Kraljevstvu nastali su prevashodno da zaštite monarhiju i Bogom dano pravo vladavine potomaka Henrija VIII, za koje su pre svega katolički pamfleti tvrdili da su vanbračni i time nelegitimni. Napad na Anglikansku Crkvu se time u suštini tumačio kao napad na državu. Usled toga, napad na druge religije nije na sličan način bio sankcionisan. Kroz istorijski razvoj, primena ovih zakona počela je da se ograničava na zabranu sadržaja koji mogu da izazovu nemire. Poslednji slučaj blasfemije zabeležen je 1977, kada je Meri Vajthaus tužila časopis Gay News jer je objavio pesmu u kojoj je Isus predstavljen kao predmet homoseksualne žudnje i čina, što po tužilji vređa osećanja vernika. Godine1979. u slučaju Vajthaus v. Lemon, Kuća Lordova potvrdila je postojanje i kontinuiranu primenu zakona o blasfemiji (Safran 2005: 89). 
Verska osećanja pripadnika drugih veroispovesti nisu bila na slični način tretirana, što se moglo videti tokom tzv. Afere Ruždi.

Roman Satanski stihovi Salmana Ruždija objavljen 1989. godine izazvao je burne reakcije. Organizovani su protesti muslimana u UK i širom sveta, primerci knjige su javno spaljivani, ajatolah Homeini je izrekao fatvu koja je dovela do ubistava i pretnji ubistvima; takođe, pred sudom $\mathrm{u}$ Velikoj Britaniji našla se tužba za blasfemiju, koja je odbačena sa obrazloženjem da je Anglikanska vera jedina koja je zaštićena zakonom (Berlinerblau 2005: 3). Divizioni sud je potvrdio 1991. godine da zakon od bogohuljenja štiti samo hrišćanstvo, ne i druge veroispovesti, a zakon o blasfemiji konačno ukinut tek 2008. godine, posle kampanje koja je trajala 30 godina. Prethodno doneseni Zakon o rasnoj i verskoj mržnji iz 2006. pokušava da uspostavi ravnotežu između slobode govora i prava na zaštitu od govora mržnje. Odeljak 29J definiše šta jeste a šta nije podsticanje verske mržnje i podvlači da se ničim ,ne zabranjuje diskusija, kritika, izražavanje antipatije, nesviđanja, podsmeha, uvrede ili povrede određene veroispovesti ili verovanja i praksi“" kao ni ,,prozelitizam ili pak podsticanje da vernik prestane da praktikuje svoju religiju ili sistem verovanja“ (Zucca 2012: 25-26).

Malta, u kojoj je Rimokatolička crkva zvanična veroispovest, u Krivičnom zakoniku određuje sankcije za vređanje verskih osećanja rimokatoličke vere ili drugog „,kulta koji toleriše država“, zvanično tretirajući tako sve priznate religije jednako u ovom aspektu. Slično ovome, danski krivični zakonik zabranjuje ismevanje ili vređanje veroispovesti „legitimne verske zajednice“. Danska koja ima svoju zvaničnu Folkekirken dozvoljava postojanje drugih verskih zajednica, ali obavezuje sveštena lica na njihovom čelu da dobro znaju danski jezik i da obećaju da će se pridržavati zakona i vladinih odluka, pa Inger Dibek navodi da su pojedini ,imami kritikovani zbog nepoštovanja danskih temeljnih kulturnih vrednosti i za vršenje političke propagande“" (Robbers 2005: 70). Danska takođe kažnjava širenje tvrdnji kojima se ugrožava grupa ljudi na osnovu rase, boje kože, porekla, vere ili seksualne orijentacije. Stranka ekstremne desnice Dansk Folkeparti je ovaj potonji zakon kritikovala, zahtevajući pravo da izraze kritičko viđenje doseljenika, posebno muslimana (Robbers 2005: 78). Čuveni kontroverzni slučaj danskih karikatura iz 2005. pokazao je da se ipak ova dva zakona ne tumače preterano bukvalno, bar kad su muslimani u pitanju. Časopis Jyllands-Posten objavio je tada na naslovnoj strani 12 karikatura Muhameda, od kojih su se neke mogle tumačiti kao uvredlji- 
ve za islamsku veroispovest, a neke pak za muslimane kao grupu. Usledili su nasilni protesti koji su uključivali paljenje danskih zastava i diplomatskih predstavništva. Danski sud je odbacio tužbu koju je podnela islamska zajednica.

Švedska je uvela novi sistem odnosa 2000. godine, međutim, po Larsu Fridneru ne bi se ipak moglo reći da je do potpunog zakonskog razdvajanja države i crkve došlo. Pravno se Švedska crkva tretira na drugačiji način od ostalih verskih zajednica i postoji poseban Zakon o Švedskoj crkvi (Robbers 2005: 371). U parohijskim crkvama održavaju se školske svečanosti povodom kraja godine i dodela diploma, u kojima učestvuju sveštenici, ali čiji je sadržaj sekularan. Sveštenici Švedske crkve, kao ni ostali vernici, nemaju obavezu da budu verujući - smatra se da obavljaju korisnu javnu funkciju bez nužne religijske komponente.

\section{Pastor Oke Gren (̌̌vedska)}

Slučaj iz Švedske koji je odjeknuo širom sveta tiče se i slobode govora i slobode veroispovesti. Oke Gren, pastor Švedske Pentakostalne Crkve, osuđen je, zbog propovedi u kojoj je osudio homoseksualce, za agitaciju protiv grupa pred okružnim sudom na mesec dana zatvora. Nakon što je pred Apelacionim sudom oslobođen optužbi, glavni tužilac Švedske izneo je slučaj pred Vrhovni sud. U zakonu koji zabranjuje agitaciju protiv određenih grupa stanovništva dodata je, naime, 2002. godine seksualna orijentacija na spisak zaštićenih karakteristika. Tužilac je naveo da protiv ovoga ne mogu štititi niti sloboda govora niti sloboda veroispovesti. Vrhovni sud je, međutim, 2005. konačno presudio da je Evropska konvencija o ljudskim pravima u kojoj se ova dva prava garantuju, iznad švedskog zakona, te da se presuda ukida jer ne bi bila potvrđena pred Evropskim sudomza ljudska prava.

Kako je do ovoga došlo? U svojoj crkvi u Borgholmu, Gren je odrŽao propoved u kojoj je homoseksualnost kao podrazumevanu ,seksualnu perverziju“ okarakterisao kao „nenormalni, užasni rak na telu društva“. Pritom je rekao da je nemoguće biti hrišćanin i homoseksualac istodobno. Očigledno je želeo publicitet: predstavnici medija su bili pozvani na ovu propoved, iako se ipak nije pojavio niko; zbog toga je Gren zatim objavio sažetak propovedi u lokalnim novinama, nakon čega ga je predstavnik jedne LGBT organizacije slučaj prijavio policiji. 
Širom sveta je odjeknula već prva presuda. Dok su jedni pozdravljali pobedu za ljudska prava i toleranciju, drugi su je videli kao napad na slobodu veroispovesti i slobodu govora, što su takođe osnovna i priznata ljudska prava. Roul Akeson iz hrišćanske grupe Network Europe organizovao je demonstracije podrške Grenu, dok su drugi držali kontramiting, protestujući protiv homofobije. Akeson je izjavio da nema problem sa homoseksualnim ljudima niti je lično 'anti-gej', ali se zalaže za slobodu govora i mogućnost da svako propoveda svoje shvatanje Biblije, te da ovaj zakon efektivno sprečava neke Šveđane da to rade i stoga predstavlja ozbiljan problem.

Možda naoko deluje paradoksalno da država koja de facto ima nacionalnu crkvu na ovaj način ograničava slobodu veroispovesti i govora, ali možda je onda neophodno podsetiti na reakcije koje je u Švedskoj izazvala izložba Ecce Homo Elizabet Olson Valin 1998. godine. Izložba fotografija na kojima je Isus prikazan među LGBT osobama, i u nekim tumačenjima kao i sam pripadnik tih populacija, nakon pojedinačnih incidenata i izliva gneva dovela je do produktivnih javnih debata o religiji i zajednici. Nakon što je izložba prikazana u katedrali u Upsali a zatim i u zgradi Parlamenta, što je simbolički učvrstilo slaganje crkve i države po ovom pitanju, Švedska je efektivno dostigla konsenzus o prihvatljivom obliku hrišćanstva i bivanja Šveđaninom: pravi hrišćanin i pravi Šveđanin, naime, mora uključivati homoseksualne braću i sestre, odnosno sunarodnike. Isključivati u ovom slučaju znači biti isključen iz kolektivnog identiteta (Igrutinović i Van Den Berg 2020). Jasno je da se ova vrednost u slučaju Gren pokazala kao neprikosnovena svetinja za švedsko društvo, iako je Vrhovni sud na kraju odlučio da ispoštuje konvencije EU.

Ukoliko je moguće doneti neki zaključak vezan za ishode konflikata u ovom tipu država, moglo bi se reći da interesi većinskog javnog mnjenja igraju presudnu ulogu.

\section{Francuski model: laïcité}

Države koje u potpunosti razdvajaju crkvu i državu, zvanično smeštajući religioznost u domen privatnog, jesu Francuska, Holandija, Irska i Slovenija. Slovenija se još uvek profiliše i nalazi se na ovom spisku uglavnom jer izričito zabranjuje konfesionalnu veronauku u prostorijama javnih 
škola i nema nikakve odredbe vezane za povlastice upućene verskim zajednicama.

Težnja ka što većoj odvojenosti crkava od države gotovo po pravilu nastaje ne zato što religija istorijski ne igra nikakvu ulogu u životima njihovim građana, već upravo obratno. Holandija je tako do modela sekularnosti došla kroz istorijski turbulentne odnose među religijama,kroz periode obavezne verske pripadnosti svakog lica starijeg od 14 godina s jedne, i zabrane javnih bogosluženja s druge strane (Robbers 2005: 331). Krivični zakonik zvanično sankcioniše javno bogohuljenje, ali primena ovog zakona je malo verovatna u praksi.

Irska je do modela razdvojenosti došla nakon presude Vrhovnog suda iz 1972. godine kojim se odbacuje doslovno tumačenje člana 44.1(2) Ustava iz 1937. kojim se priznavao poseban položaj Rimokatoličkoj crkvi, nakon čega je referendumom doneta odluka o brisanju ovog člana. A u članu Ustava koji garantuje slobodu izražavanja i dalje stoji da je objavljivanje ili iskazivanje „svetogrđa“ krivično delo; međutim, odluka Vrhovnog suda iz 1965. godine napominje da ne postoji ustavna ili zakonska definicija svetogrđa jer više ne postoji zakonom utemeljena crkva, te se smatra da je u praksi nemoguće pokretanje postupka u ovakvom slučaju. Slučaj komičara Stivena Fraja iz 2017. godine, čiji je nastup u emisiji „Smisao života“ (The Meaning of Life) prijavljen za kršenje zakona protiv blasfemije policija formalno i vrlo kratko istražila po službenoj dužnosti, iako je izazvao burne reakcije irske i šire evropske javnosti, u suštini je dokazao ovu tvrdnju (Cox 2019).

Francuska je posle Buržoaske revolucije 1789. uvela razdvojenost države i crkve, nakon čega su usledili progoni pripadnika Katoličke crkve, posebno velikodostojnika koji su viđeni kao deo korumpirane vladajuće elite. Bonaparta je izdejstvovao verski mir koji je rezultovao Konkordatom potpisanim 1801. Do potpunog prekida diplomatskih odnosa sa Svetom stolicom ipak je došlo 1904. godine. Zakon iz 1905. uvodi režim stroge razdvojenosti crkve i države koji i danas traje. Francuska posledično nema zakone o blasfemiji ni vređanju osećanja vernika ili pripadnika bilo koje filozofije, što su mnogi sa čuđenjem primetili nakon masakra u redakciji časopisa Charlie Hebdo u januaru 2014. kada su islamski teroristi automatskim oružjem pokosili nekolicinu karikaturista i drugog osoblja. Salman Ruždi se tada oglasio kritikujući komentatore koje je nazvao „the But brigade“ - one koji su na pokolj reagovali sa „Verujem u slobodu govora, 
ali“ - i izneo svoj stav da je sloboda govora ili nedeljiva ili ne postoji. Može nam se ne sviđati humor Šarli Ebdo koji nije uvek smešan, rekao je Ruždi, ali to nikome ne oduzima pravo na govor.

Šarli Ebdo je svojim oštrim i ne baš uvek ukusnim humorom ciljao pripadnike svih religija; francuski sekularizam, čini se, u poslednje vreme na udaru najviše ima islam, iako je većina francuskih muslimana izrazito sekularna i praktikovanje vere svodi na formalnosti poput obeležavanja velikih praznika (Safran 2005: 61).

Zakonom iz 2004. godine koji je izazvao buru debata zabranjeno je isticanje upadljivih verskih simbola u državnim školama, kao i nošenje hidžaba u učionicama i javnim institucijama. Zakon je sročen tako da naizgled ne diskriminiše, jer jednako tretira sve veroispovesti. Međutim, u praksi je jasno u kojoj meri je ovaj zakon proizvod kulture u kojoj je hrišćanstvo neutralno i podrazumevano kao standard. Ne postoji nijedna situacija u kojoj bi hrišćanin imao potrebu da ističe upadljive verske simbole - čak ni neupadljivi simboli poput malog krsta (koji je dozvoljeno nositi oko vrata) nisu ni u jednom tumačenju verska obaveza hrišćanina. S druge strane, hidžab ili kipa nisu simboli per se, već su u nekim iteracijama islama i judaizma materijalna i opipljiva obaveza vernika. Zuka navodi podatak da je posledica primene ovog zakona često bila isključivanje najranjivijih kategorija učenika iz sistema javnog obrazovanja (Zucca 2012: 9).

Dva manja incidenta s kraja 2019. godine aktuelizovala su ovu debatu u francuskoj javnosti. Žilijan Odul, ministar iz desničarske stranke RN, na Tviteru je objavio snimak gde se vidi kako insistira da majka koja je pratila grupu dece u školskoj poseti regionalnom parlamentu skine hidžab. Deca su bila vidno uplašena, pa je majka odlučila da napusti prostoriju.

Zatim je nekoliko dana kasnije poseta grupe učenika vatrogasnoj stanici severno od Pariza otkazana jer su dve majke koje su pratile svoju decu nosile hidžab, te šef vatrogasne službe nije dopustio grupi da uđe u stanicu. U oba slučaja incidenti nisu proistekli iz primene zakona - koji se odnosi samo na učenike i nastavnike u školi, ne njihove roditelje van škole - ali ilustruju interpretaciju namere i duha zakona koja očito postoji u jednom delu javnosti. 


\section{Slučaj Sing (Francuska)}

Zakon iz 2004. je podstakao međunarodne burne reakcije. Najviše se govorilo o statusu učenica koje nose hidžab, ali su ovim zakonom na udaru i dečaci koji su ortodoksni Jevreji (koji nose kipe) i Siki (koji nose turbane). Učenici koji su Siki su se više puta pred Evropskim sudom za ljudska prava neuspešno žalili zbog diskriminacije u francuskom obrazovnom sistemu. Komitet za ljudska prava Ujedinjenih nacija je pak u slučaju Sing v. Francuska u novembru 2012. doneo drugačiju odluku kojom potvrđuje slobodu veroispovesti.

Slučaj Sing v. Francuska započeo je 2008. godine i pokrenuo ga je Bikramdžit Sing, državljanin Indije sa prebivalištem u Francuskoj koji je bio učenik srednje škole koji je nosio keski pre nego što je sporni zakon donet. Keski je manji turban, odnosno parče tkanine koje delimično pokriva kosu i predstavlja alternativu većem koji obično nose odrasli muškarci. U religiji Sika, turban za muškarce smatra se za neizostavni element praktikovanja vere, a ne za njen 'simbol'. Time bi sloboda veroispovesti u ovom slučaju bila suzbijena, ne samo ograničena u svojim manje bitnim manifestacijama. Sing je keski nosio kao kompromis između zahteva svoje religije za nošenjem turbana i principa sekularizma. Škola mu je zabranila ulaz, izolovala ga u drugoj učionici držeći ga tamo nedeljama samog i bez nastave, i na kraju ga izbacila.

U tužbi se navodi diskriminacija na osnovu porekla i povreda prava na slobodu veroispovesti i tvrdi se da čak i da je dečak skinuo keski, njegova duga kosa i dalje bi bila vidljivi simbol vere - što je u srazu sa nekim svedočenjima po kojima su učenice islamske veroispovesti koje su u ime kompromisa nosile samo simboličnu širu traku za kosu sankcionisane, dok su ostale učenice mogle da nose slične predmete kao modne detalje bez problema. Komitet je u odluci primetio da keski nije puki simbol vere, već deo njenog praktikovanja, te da država ima pravo da ograniči praktikovanje religije ali samo u onoj meri u kojoj bi ono ugrozilo javni red i mir ili fundamentalna prava i slobode drugih građana. U ovom slučaju, ovi obziri su prekoračeni, a prava nepotrebno uskraćena.

Slični slučajevi su imali suprotne ishode pred Evropskim sudom za ljudska prava. U slučajevima Randžit Sing i Džasvir Sing v. Francuska, na primer, učenici su takođe izbačeni iz škole jer nisu uklonili keski. Sud je presudio u korist Francuske, kao i u sličnim prethodnim slučajevima. 
Ukoliko je moguće doneti neki zaključak vezan za ishode konflikata u ovom tipu država, moglo bi se reći da interesi većinskog javnog mnjenja takođe igraju presudnu ulogu.

\section{Nemački model: saradnja}

Kao države koje pripadaju 'nemačkom' modelu navode se Nemačka, Poljska, Belgija, Mađarska, Austrija, Portugal, baltičke države, Italija i Španija. Neki autori potonje dve države izdvajaju u zasebnu podvrstu koja ispoljava veći stepen sekularnosti od onog koji postoji u, recimo, Nemačkoj. Nemačka po Balašu Šandi ima „,model koordinacije“, dok se italijansko-španski model, primenjiv i na Mađarsku, može nazvati „benevolentna odvojenost" (Robbers 2005: 184).

Austrija dozvoljava ritualno klanje životinja i nošenje marame, dok Nemačka u nekim federalnim jedinicama zabranjuje „isticanje verskih simbola" u školi. Poslednjih godina, osim hidžaba, u žižu javnosti izlaze i debate oko zakona vezanih za obrezanje i ritualno klanje životinja po kašrutu, odnosno halalu.

Različite se formulacije koriste da ograniče slobodu govora u pitanjima vezanim za religiju. Nemačka, kao i mnoge druge države, zabranjuje izazivanje mržnje prema verskoj grupi, dočim Austrija zabranjuje i ismevanje ili omalovažavanje osobe ili objekta koji je sakralan za crkvu ili versku zajednicu „u okolnostima u kojima je verovatno da takvo ponašanje izazove nemir“. U Poljskoj je kažnjivo povrediti verska osećanja drugog, dok Kipar ima „klevetu vere“ $i$, uvredu verskih osećanja rečima ili delom“ u krivičnom zakoniku.

\section{Isus \& Marija: od filma do reklame (Austrija i Litvanija)}

Često navođen slučaj Institut Oto Preminger v. Austrija našao se pred Evropskim sudom za ljudska prava ranih devedesetih godina. Film koji je oslikavao Svetu porodicu u uvredljivom svetlu trebalo je da bude prikazan, ali su lokalne vlasti administrativnom sanckijom sprečile projekciju (Zucca 2012: 26). Sporni film pod nazivom Das Liebeskonzil zasnovan je na drami iz XIX veka čiji je autor svojevremeno osuđen za „zločine protiv vere“. U njemu se prikazuje zavera Boga Oca, Isusa i Bogorodice - prikazanih u najmanju ruku satirično - da na svet puste sifilis kao kaznu za gre- 
he, i to počevši od vladara i visokih pripadnika crkvene hijerarhije (Pearson 2017: 60). Po presudi Evropskog suda za ljudska prava, mera lokalnih vlasti je bila opravdana da bi se sprečile burne i potencijalno nasilne reakcije. U odluci donetoj 1994. navodi se da su, iako film ima „umetničku vrednost“ i daje „doprinos javnoj debati“, austrijske vlasti dobro postupile time što su ga konfiskovale a projekciju zabranile, jer je to bilo u cilju održavanja verskog mira u dominantno katoličkoj regiji Tirol.

S druge strane, eksperti Evropskog suda za ljudska prava navode da jedna država ne može sankcionisati svetogrđe samo po sebi, čak i ukoliko šokira veliki deo stanovništva. U slučaju Sekmadienis Ltd. v. Litvanija koji je pred Evropskim sudom za ljudska prava bio 2018. godine vidi se razvoj shvatanja suda u poslednje dve decenije. Sud je ovde odlučio da su pomesni sudovi kaznivši kompaniju zbog reklame ugrozili njeno pravo na slobodu izražavanja.

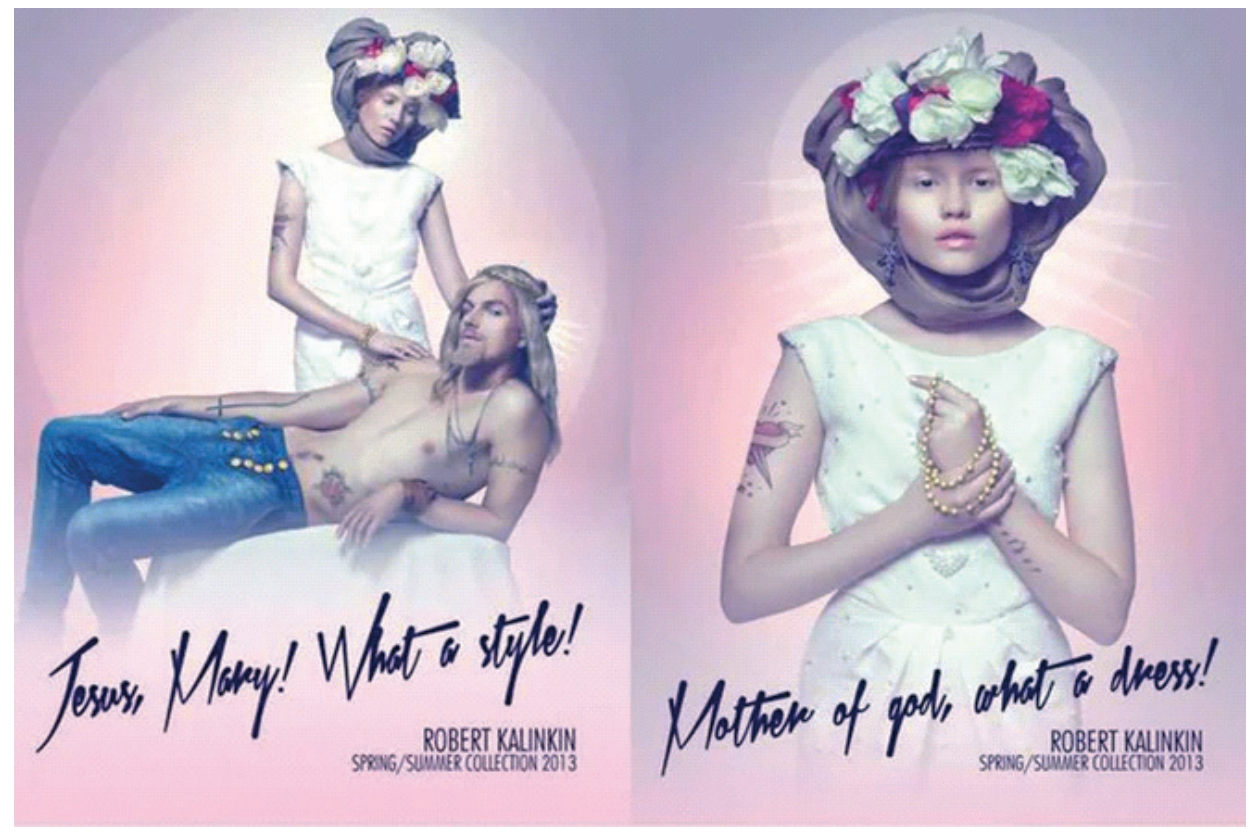

Sporne reklame iz 2012. godine prikazivale su figure Isusa u farmerkama i Bogorodice u beloj haljini, a lokalni sud je utvrdio da reklame krše Zakon o oglašavanju time što vređaju javni moral, što je Evropski sud za ljudska prava na kraju osporio, iako reklama svakako ima manje umetničke vrednosti i doprinosa debati od filma, i premda je za sud ovaj put izgleda bilo nebitno što Litvanija ima katoličku većinu. Jasno je da su se shva- 
tanja i reakcije promenile za ovo vreme. Takođe je jasno da je potencijal da se izazovu nemiri i nasilje važan faktor u odlukama.

\section{Madona u duginim bojama (Poljska)}

Slučaj koji se nedavno pojavio pred sudom u Poljskoj nedavno je uznemirio svetsku javnost. U njegovom centru je aktivistkinja i psihoterapeutkinja Elzbeta Podlesna koja je oreol na ikoni Bogorodice oslikala u duginim bojama u znak podrške LGBT populaciji. Ikona koja je koristila za uzor poznata je kao „Crna Madona“ iz manastira Jasna Gora, i simbolično je krunisana kao „Kraljica Poljske“ u XVII veku.

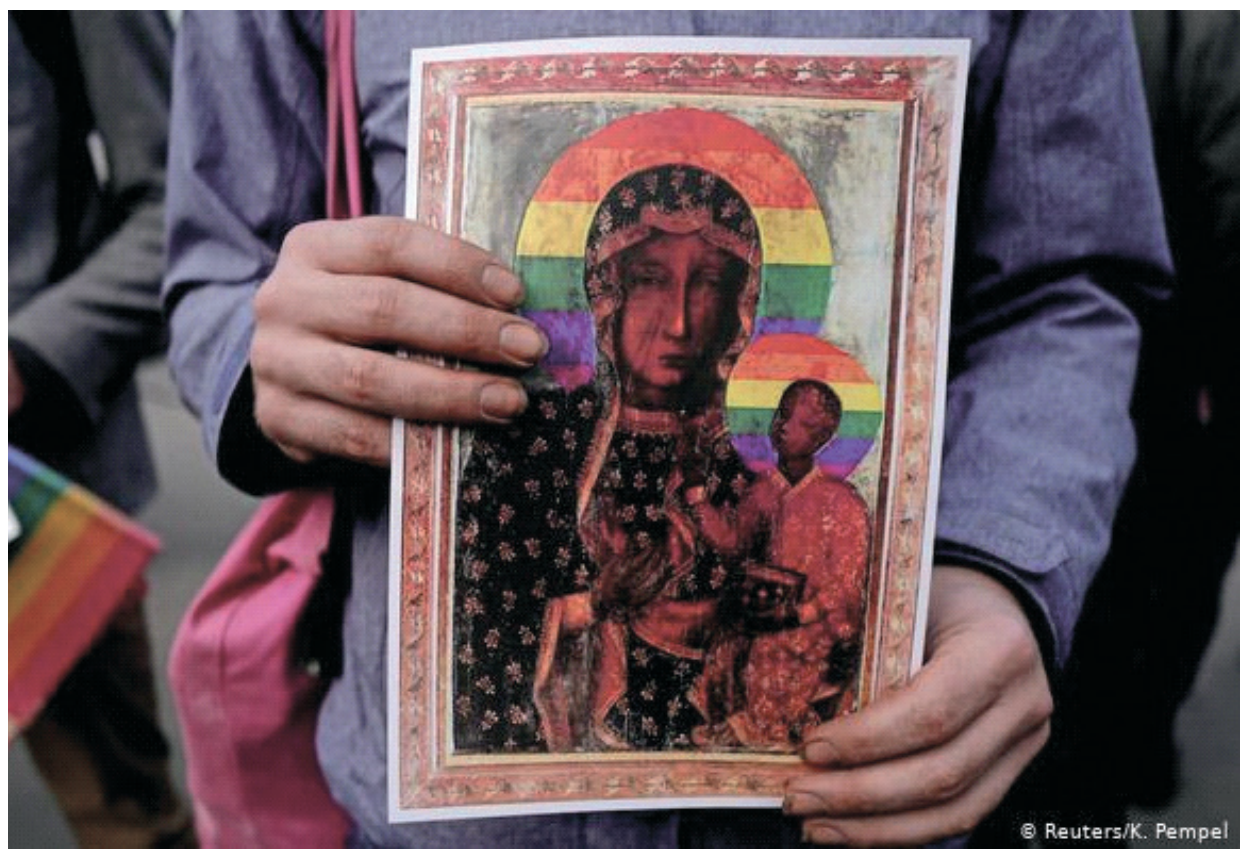

Podlesna je uhapšena, stan joj je pretresen, a svi elektronski uređaji konfiskovani, nakon čega je nekoliko sati ispitivana u policijskoj stanici. Zbog kršenja zakona koji zabranjuje ,javno vređanje verskih osećanja ili skrnavljenja ritualnog predmeta" navodilo se da bi mogla da dobije dve godine robije. Dok poljski ministar unutrašnjih poslova na Tviteru hvali policiju i osuđuje ,skrnavljenje ikone Bogorodice, koju Poljaci smatraju svetom“, Podlesna odbija optužbe da je u pitanju bilo kakav napad. Navodi da je njena poruka prosto da bi Sveta Majka zaštitila sve ljude drugači- 
je seksualne orijentacije. Po poslednjim navodima, Podlesna je 2021. oslobođena optužbi. Ukoliko je moguće doneti neki zaključak vezan za ishode konflikata u ovom tipu država, moglo bi se reći da potencijal da se izazovu konflikti i nemiri igraju presudnu ulogu.

\section{Zaključak}

Model sekularnosti jedne države, kao što smo videli, ne govori mnogo o njenom društvu. Zvanična crkva jedne države, poput Švedske, može biti dosta sekularizovana vekovima relativnog mira i ne uticati mnogo na svakodnevicu njenih građana; s druge strane, strogo sekularna država, poput Holandije, može biti proizvod burnih istorijskih perioda u kojima je religija igrala - i možda još uvek igra - jaku ulogu pa je stoga morala biti bar delimično prognana iz državne, pa i javne sfere. Proces sekularizacije na zapadu pacifikovao je i ublažio, ipak, najekstremnije forme religioznosti i stvorio pozamašnu grupu vernika koji se u velikoj meri slažu sa nereligioznim građanima po mnogim bitnim društvenim i političkim pitanjima. Ovu grupu Berlinerblau naziva „sekularnim vernicima“ (Berlinerblau 2005: 3).

Ovo svakako bar delimično potiče od identitetske dimenzije veroispovesti i njihovih odnosa moći u jednom društvu: dominantni verski identitet se u društvima obično lako i bez gubitaka otvara, pacifikuje, te u nekim slučajevima tolerancija postaje oznaka i signal privilegije i elitizma. Marginalizovani verski identiteti se kao odgovor na sekularizaciju javnog prostora pak mogu zatvoriti u uske krugove, radikalizovati, što ih zatim dodatno marginalizuje, kao što smo videli u slučajevima dece koja bivaju ispisana iz škola u Francuskoj, što ih izopštava i smanjuje potencijale za zaradu u budućnosti.

Možda je bolje pitanje možemo li uopšte govoriti o istom modelu sekularnosti za sve građane? Razlike u praktičnom tretmanu dokazano postoje $\mathrm{u}$ odnosu na istorijsko dominantne $\mathrm{s}$ jedne $\mathrm{i}$ istorijski potlačene ili marginalizovane verske zajednice $\mathrm{s}$ druge strane. U prevodu, imigranti, posebno muslimani, mogu se, recimo, podjednako lako diskriminisati pod različitim modelima sekularnosti. U Grčkoj mogu biti uhapšeni zbog prozelitizma suprotnog zvaničnoj državnoj crkvi. U Francuskoj mogu na osnovu nošenja hidžaba biti isključeni iz obrazovanja. Belgija nema de iure povlašćenu crkvu, ali da bi država plaćala veroučitelje jedne religijske 
zajednice, nužno je da ova bude jasno hijerarhijski ustrojena i da deluje na teritorijalnoj osnovi, što opisuje katoličku crkvu, ali ne i islamsku zajednicu, tako da je de facto stanje drugačije (Robbers 2005: 38). Dominantna kultura očito ima tendenciju da se reprodukuje bez obzira na model sekularnosti i možda je u tom svetlu i najpraktičnije gledati slobodu veroispovesti i slobodu govora.

Sloboda veroispovesti ima različite stupnjeve. U EU obično ne nailazi na probleme ukoliko se drži u privatnoj sferi i dovoljno liči na religioznost koju i hrišćanska kultura propisuje - privatne molitve i odlazak u bogomolju jednom nedeljno i/ili za praznike. Do problema dolazi kad postoje aspekti koji nisu u skladu sa dominantnom kulturom, bilo da je to obrezivanje dečaka, ritualno klanje životinja, nošenje marame, keskija ili kipe, ili javna osuda homoseksualnih aktivnosti. Insistiranje na potpunoj asimilaciji (čak i u onim aspektima koji ne nanose štetu drugima niti remete red i mir) neki autori su videli kao prikrivenu želju za kontinuiranom dominacijom nad Drugim koji će biti kao mi, ali tek u budućnosti, a sada nam treba kao Drugi: marginalizovani i korisni, radnici najtežih i najprljavijih poslova, u čekaonici istorije (De Vries 2006: 449).

Sloboda govora se takođe može ograničiti na različitim stupnjevima: od izvrgavanja podmehu ideja, doktrina, koncepata, simbola i figura, preko vređanja osećanja vernika, do izazivanja mržnje prema pripadnicima jedne veroispovesti. Po modelima sekularnosti, motivi ograničenja slobode govora idu od zaštite dominantne religije, preko zaštite identiteta bitnih grupa, do zaštite bezbednosti konkretnih ljudi koji pripadaju manjinama, mada ni ovo nije uvek jednostavno.

Ukoliko prihvatamo evropsku ideju da se sloboda govora opravdano ograničava u slučajevima pretnje, poziva na nasilje i ugrožavanja bezbednosti - naspram američke ideje apsolutne slobode govora - onda nam ostaje da preispitamo prve dve opcije. Ako ne prihvatamo stari argument iz natprirodnog da se žrtveni jarac koji vređa božanstvo mora ukloniti iz naroda ne bi li se sprečila kolektivna kazna, kolektivni identitet okupljen oko određenih simbola ostaje kao jedino što zbilja zahteva zaštitu pred zakonom - ali da li ima pravo na to nauštrb slobode govora? Da li je zaštita osećanja vezanih za kolektivni identitet pravo na bilo koji način i može li se onda primeniti na bilo koji grupni identitet, odnosno pripadnost bilo kojoj grupi na dobrovoljnoj osnovi? Mogu li navijači zahtevati kazne za one koji ismevaju zastave i grbove njihovih klubova? Videli smo da Dan- 
ska, koja ima formu zabrane svetogrđa, nije reagovala na karikature koje su bile blasfemične za islamske vernike. Neki kolektivni identiteti očito nisu predviđeni da budu zaštićeni - a možda prosto ne bi trebalo da to očekuje nijedan.

Kroz slučajeve koje smo videli gde se ograničava sloboda veroispovesti, sloboda govora, ili obe, otkriva se šta je zbilja „sveto“-odnosno neprikosnoveno - a šta tabuisano u jednom društvu; sveto ne mora nužno biti na bilo koji način sakralno, ne mora imati veze sa religijskim, sveto biva ono što se vidi kao osnova zajedničkog identiteta. Homoseksualnost ili heteroseksualnost, mir i bezbednost, zaštita manjina, sloboda da se imigranti kritikuju, sloboda govora, sloboda veroispovesti, pa čak i sama sekularnost mogu biti svetinje koje se ne dovode u pitanje.

Ono što primeri pokazuju jeste da Pera prosto nije u pravu kada tvrdi da „Evropa, pod izgovorom slobode izražavanja, štiti bogohulna umetnička dela u odnosu na hrišćanstvo, ali zaustavlja tuistu slobodu kada se radi o satiričnom nepoštovanju islama“ (Pera 2010: 26). Slična panika podigla se kada je Evropski sud za ljudska prava 2019. potvrdio presudu jednoj predavačici koja je Muhameda nazvala pedofilom, ali je takođe nedavno osudio presudu koju je Azerbejdžan doneo protiv dvojice novinara koji su žestoko kritikovali islam. Neki su prvu presudu okarakterisali kao posebnu zaštitu za islam, ali posle potonje se možda ipak pre može uočiti tendencija da se u jednoj državi uzme u zaštitu manjinsko mišljenje.

I upravo bi takav prioritarizam možda jedini mogao da posluži kao osnova novih modela sekularnosti: empatija pre svega prema najugroženijima, insistiranje na autentičnosti motiva svakog čina i iskaza, a umesto autoritarnosti uvreženih identiteta postavljanje pitanja i preispitivanje svih crno-belih binarnih opozicija.

\section{Literatura}

Asad, Talal, Judith Butler, Saba Mahmood, Wendy Brown, Is Critique Secular? Blasphemy, Injury, and Free Speech, University of California, Berkeley, 2009.

Berlinerblau, Jacques, The Secular Bible: Why Nonbelievers Must Take Religion Seriously, Cambridge University Press, 2005.

Bigović, Radovan (ur.), Hrišćanstvo i evropske integracije, Hrišćanski kulturni centar/ Fondacija Konrad Adenauer, Beograd, 2003.

Cox, Neville, ,Stephen Fry, the Meaning of Life, and the Problem with Irish Blasphemy Law“, Oxford Journal of Law and Religion, 2019, 8, 247-269. 
De Vries, Hent (ur.), Political Theologies: Public Religions in a Post-Secular World, Fordham University Press, New York, 2006.

Igrutinović, Danica i Mariecke Van Den Berg, „Ecce Homo in Sweden and Serbia: state, church and blasphemy“, Contested Privates, Palgrave, 2020. (u štampi)

Jablanov Maksimović, Jelena i Andrijana Krstić (ur.), Crkva u pluralističkom društvu, Konrad Adenauer, Zrenjanin, 2009.

Lerner, Natan, Religion, Secular Beliefs and Human Rights: 25 Years After the 1981 Declaration, Martinus Nijhoff Publishers, Leiden/Boston, 2006.

Lübbe, Hermann, Religion nach der Aufklärung, Verlag, 1986. Srpsko izdanje Religija posle Prosvetiteljstva, prev. Slobodan Damnjanović, Albatros plus, Beograd, 2012.

Pearson, Megan, Proportionality, Equality Laws, and Religion: Conflicts in England, Canada, and the USA, Taylor\&Francis, 2017.

Pool, Ithiel de Sola, Technologies of freedom, Belknap Press, Cambridge, MA, 1983.

Pera, Marcello, Perché dobbiamo dirci cristiani. Il liberalismo, l'Europa, l'etica, Mondadori 2008. Srpsko izdanje Zašto se moramo zvati hrišćani: Liberalizam, Evropa, etika, prev. Darjana Rančić-Jerković, Službeni glasnik, Beograd, 2010.

Robbers, Gerhard (ur.), State and Church in the European Union, Nomos, Baden-Baden, 2005. Srpsko izdanje Država i crkva u Evropskoj uniji, prev. Nikola Selaković i Andrija Katančević, PBF, Beograd 2012.

Safran, William (ur.), The Secular and the Sacred: Nation, Religion and Politics, Frank Cass, London/Portland, 2005.

Zucca, Lorenzo, A Secular Europe: Law and Religion in the European Constitutional Landscape, Oxford University Press, Oxford, 2012. 


\title{
Danica Igrutinović
}

The Faculty of Media and Communications

Belgrade, Serbia

danica.igrutinovic@fmk.edu.rs

\section{FREEDOM OF RELIGION AND/OR FREEDOM OF SPEECH IN POSTSECULAR EUROPE}

\begin{abstract}
Summary
This paper tackles freedom of religion and freedom of speech in the domain of critique of religion in EU member states through three main models (French, German and English) that they employ in the organization of their relationship with the religious communities of their citizens. It mentions potential problems of these models of secularism in the domains of freedom of religion and freedom of speech, citing for each model at least a single illustration of widely known controversies from the XX and XXI centuries. The conclusion, after noticing general tendencies present in each model, raises several short theoretical questions related to secularism of the state and society - with a look at secularism in public and media space - in the postsecular world.
\end{abstract} secular

Key words: freedom of religion, freedom of speech, EU, models of secularism, post- 